\title{
Chapter 7 \\ Research in Two Case Studies: Irrigation and Land Use in the Fergana Valley and Water Management in the Lower Jordan Valley
}

\author{
Christine Bismuth, Sebastian Hoechstetter, and Oliver Bens
}

\begin{abstract}
This chapter aims to present an overview of the two case studies "Irrigation and land use in the Fergana Valley" and "Water management in the Lower Jordan Valley". It names the main criteria and reasons for their selection as cases in the study of implications of major water engineering projects. The political and cultural conditions in these regions and the major issues and problems concerning water management are outlined in broad terms.
\end{abstract}

Keywords Fergana Valley $\bullet$ Lower Jordan Valley $\bullet$ Central Asia $\bullet$ Irrigation $\bullet$ Land use $\bullet$ Water management $\bullet$ Major water engineering projects $\bullet$ Red Sea $\bullet$ Dead Sea Conveyance Project $\bullet$ Study of alternatives $\bullet$ World Bank

\subsection{Selection of the Case Studies: A Wide Spectrum of Socio-Economic and Ecological Framework Conditions}

There are many examples and varying types of major water engineering projects (MWEPs) over the globe. The range of related technologies, resource challenges, impacts and the political and governance systems that such projects are embedded into is equally wide. In order to cover as many practical and theoretical aspects and framework settings of MWEPs, we have decided to select two case studies: the Uzbek

\footnotetext{
C. Bismuth $(\bowtie)$

Interdisciplinary Research Group Society - Water - Technology,

Berlin-Brandenburg Academy of Sciences and Humanities,

Jägerstraße 22/23, 10117 Berlin, Germany

Helmholtz Centre Potsdam - GFZ German Research Centre for Geosciences,

Telegrafenberg, 14473 Potsdam, Germany

e-mail: bismuth@gfz-potsdam.de

S. Hoechstetter $\bullet$ O. Bens

Helmholtz Centre Potsdam - GFZ German Research Centre for Geosciences,

Telegrafenberg, 14473 Potsdam, Germany
} 
parts of the Fergana Valley in Central Asia and the Lower Jordan Valley in the Middle East, which entail a broad range of issues that are relevant to the comprehensive evaluation of major water engineering projects. Furthermore, the selection of the case studies reflects the competences and experiences of the contributors to this volume, which has improved the accessibility to information and data.

The case studies cover the most prominent issues being discussed throughout the world when it comes to the implementation of MWEPs, including issues of Integrated Water Resource Management (IWRM), water governance, the "foodwater-energy nexus", ecosystem services, issues of transboundary water management, the challenges posed by climate change, political/governance instruments and societal transformation.

Both case studies are located in geopolitical hot spots, where water appears both as a source of conflict and as an occasion for cooperation. Each of the case studies reflects the weaknesses of the international law and regulations with concern to transboundary management issues. Both regions are affected by climate change with mainly negative consequences on water availability. Societal issues, political transformations and the consequences of historical decisions characterise current water management systems in the selected regions. Very different approaches are pursued in the case studies with regard to solutions for overcoming water shortages, securing energy and producing food. The regions illustrate the significant impact of state and governmental failures on the water management. In addition, the lessons learned so far both in the Fergana Valley and in the Lower Jordan Valley reveal that many problems of water management cannot be solved only within the water management sector in its own narrow definitions, but that they have to be tackled from a more general societal and economic perspective.

The Red Sea-Dead Sea (RSDS) Conveyance Project in the Middle East offers the opportunity to study a major project in its planning phase. In many countries other than Israel and Jordan respectively, seawater desalination will be a major strategy in the future for overcoming water shortages. Therefore, the Lower Jordan Valley case study may be perceived as being exemplary for countries under similar conditions. The Fergana Valley case study focuses on past decisions and the resulting path dependencies; this shows how consequences of technically driven decisions have to be dealt with by following generations.

Information and material on the case studies was collected with comprehensive literature research and analysis. In 2014, a research journey to the Fergana Valley was carried out by several authors of this volume with the support of the German Academic Exchange Service (DAAD). The central Fergana Valley irrigation systems and the role of the water users associations (WUAs) were in the focus of this research visit. Discussions with local stakeholders and decision makers and the exchange with researchers from Central Asia provided valuable insight into the regional situation.

With regard to the case study of the Lower Jordan Valley, an international workshop on the RSDS project with Israeli, Jordanian and Palestinian experts was organised in 2013. A research trip to Jordan was carried out for the preparation of this workshop, its results eventually being presented to and discussed with members of 
the Israel Academy of Sciences and Humanities. In addition, a number of Israeli, Jordanian and Palestinian experts have been interviewed.

The outcome of these extensive discussions, studies and meetings will be presented in Parts III and IV of this volume. In the following, we will provide a brief overview of the situation in the two case study regions and illustrate their similarities and differences.

\subsection{The Fergana Valley}

The Fergana Valley is situated in the "heart" of Central Asia. In ancient times, branches of the famous Silk Road crossed the valley. The valley is shared between Uzbekistan, Tajikistan and Kyrgyzstan. The Syrdarya River and some of its major tributaries cross the valley on their way to the Aral Sea (see Fig. 7.1). Its extension is limited by the surrounding mountains.

It is one of the most fertile regions in Central Asia and one of the oldest irrigation cultures worldwide. Already in the Neolithic Age, wheat and barley were watered by means of gravity irrigation. The historical extension of the irrigation is compa-

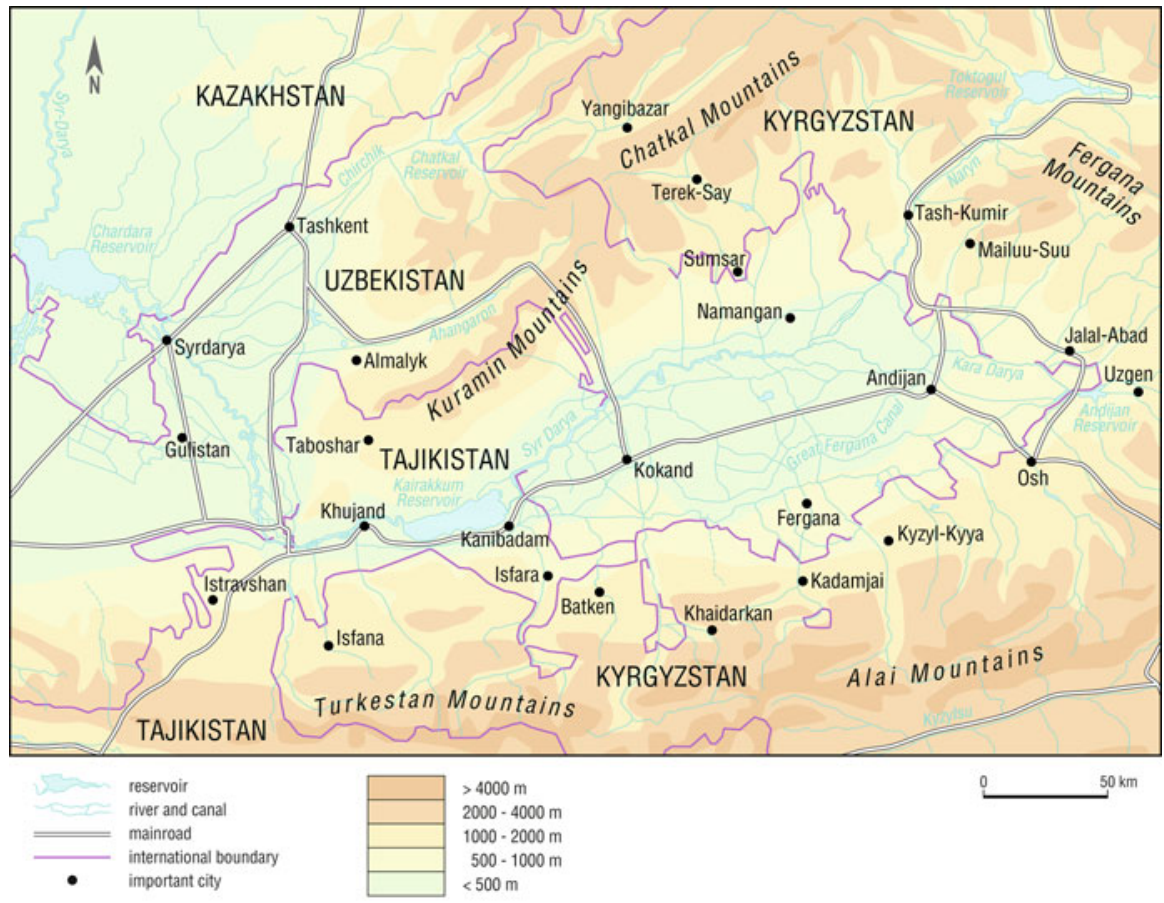

Source: based on various topographical maps

Design and Q. H. Kreutzmann / Gartography. B. Hïberer

Fig. 7.1 Topographic map of the Fergana Valley (Source: Kreutzmann 2015, in this volume, pp. 113-127) 
rable to the extension of present irrigation schemes (Francfort and Lecomte 2002). Before Russian colonisation, the valley was famous for its agricultural products such as melons, apricots, walnuts, wine and rice. Lucerne was the foundation for the valley's renowned horse breeding.

Russian colonisation in the nineteenth century is the starting point of radical changes and societal upheavals in the region referred to as "Turkestan". Turkestan, whose boarders were not precisely defined during the period of the Russian Empire, approximately comprises the current states of Turkmenistan, Kazakhstan, Kyrgyzstan, Uzbekistan and Tajikistan. The borders between these modern successors of Turkestan were established during the regime of Stalin on the basis of language and ethnicity. Today these borders are a source of conflicts and problems; as after all, the region remains intermingled, both in ethnical and economic terms.

The driving forces behind the Russian colonisation were Russia's rivalry with the British Empire and its need for cotton cultivation areas. Thus, the Central Asian agriculture was strategically relevant for the Russian Empire. From the early days of the colonisation period, cotton played a key role as an important feedstock. A central agrarian administration had been founded already in 1904. In the further course of time, a cotton production programme with a state-owned and controlled irrigation network was established. But cotton could only be successfully introduced in the Fergana Valley with the construction of railways for the transportation of the cotton to the production centres but also with the construction of factories for combing and pressing the cotton in large balls. From the remaining cotton grains, oil is produced for human consumption (Jozan 2012). It was the converging of local interests with those in the Russian textile production centres which led to the introduction of cotton in the Fergana Valley (ibid). But cotton could only be introduced by the extension of the irrigated area, as the other land was dedicated to support the needs of the local populations (ibid). Around 1910, the existing autochthone irrigation techniques could not use the waters of the Naryn and the Syrdarya which limited the extension of cotton (ibid). It was only in a later period with the construction of large-scale hydraulic works that the cotton production could be extended.

The agrarian production systems were collectivised in the 1930s. At later stages, radical changes were forced on the traditional oasis systems (Cariou 2004). Small agrarian units were merged into larger ones and traditional rural village communities were broken up. Old irrigation systems were levelled, and large irrigation channels were constructed for the benefit of a modern industrialised agricultural production with cotton as the main product.

As a consequence, the decades-long overuse of water resources, excessive cotton production and agrarian mismanagement have led to the drying up of the Aral Sea.

Along the Syrdarya, approximately 40 dams with a storage capacity of $37 \times 10^{9} \mathrm{~m}^{3}$, representing $89 \%$ of its flow capacity, were constructed between 1950 and 1980. During those years, cotton production was the main economic sector. Irrigation was more important than hydropower generation. The discrepancies already existing between hydropower and irrigation demands were moderated by the Soviet authorities (Jozan 2008).

With the collapse of the Soviet Union, the structural problems in the water management sector were aggravated, and the diverting interests of the individual states 
became evident. While the geopolitical setting of Central Asia has changed, the "old elites" still have considerable influence on the institutions of the water management sector.

The water balance, which was already fragile during the Soviet regime, has completely lost its equilibrium (Eschment 2011). Agreements that were supposed to regulate the management of water between the different states have not been respected and must be considered as failures (ICWC 2002). A line of division runs between the upstream states of the Syrdarya and Amudarya Rivers (Kyrgyzstan and Tajikistan) on the one hand and the downstream countries (Uzbekistan and Kazakhstan) on the other hand. The former are aiming at hydropower generation (particularly during the winter months) to cover their energy needs, while the latter require water mainly during the summer months to irrigate agricultural land. This relationship of dependence is illustrated in Fig. 7.2.

The hibernal water releases from the upstream dams impact the river banks and cause flooding (Jozan 2008). The climate change-induced retreat of the mountain glaciers will not only have considerable impact on water availability, but also on the seasonal distribution of the water resources. The dependency on precipitation as a source of (irrigation) water will increase. Climate change may therefore aggravate the already existing conflicts between the riparians.

The institutional settings, the role of the water users associations (WUAs) in Uzbekistan and the problems caused by the irrigation and drainage systems in the Fergana Valley constitute the focus of our analyses presented in Part III of this volume.

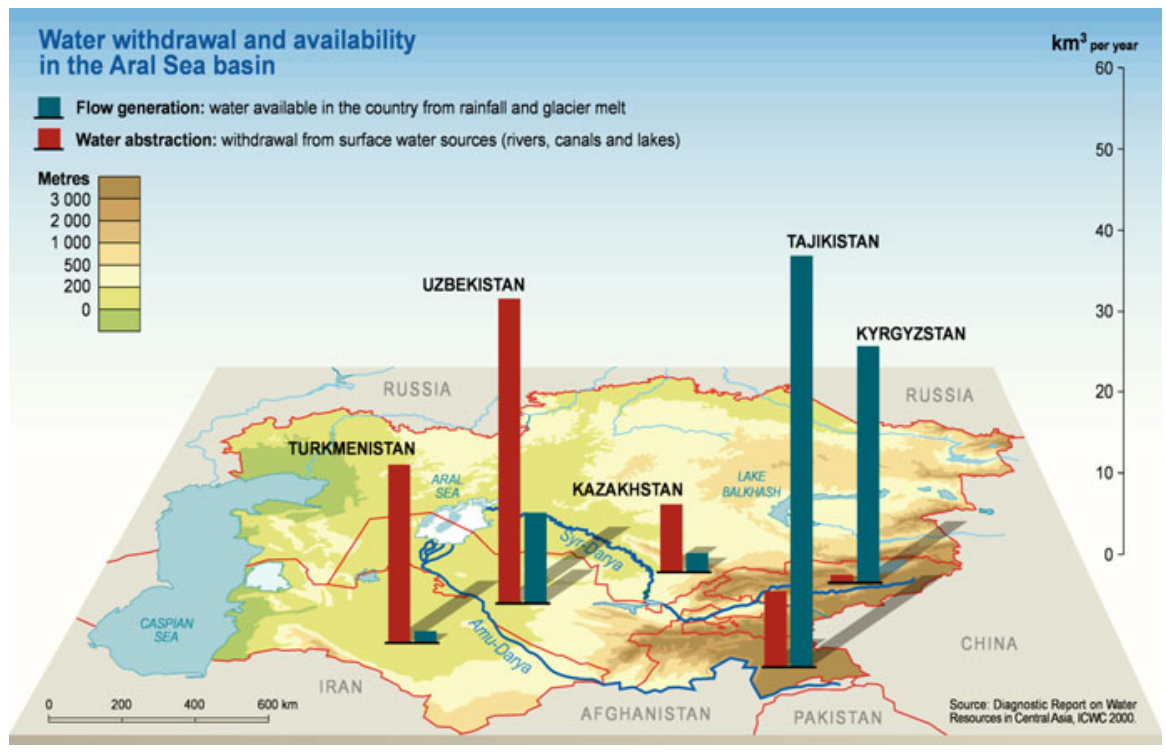

Fig. 7.2 Water withdrawal and availability in the Aral Sea Basin (Source: Rekacewicz and Novikov 2006, http://www.grida.no/graphicslib/detail/water-withdrawal-and-availability-in-aral-sea-basin_85d9) 
The transformation processes and the resulting path dependencies are examined in Kreutzmann (2015, in this volume, pp. 113-127), while the institutional legacies, the reforms and the interstate cooperation after the collapse of the Soviet Union are studied in Moss and Dobner (2015, in this volume, pp. 101-111).

The complexity of the irrigation and drainage systems and the resulting limitations are focused on in Kenjabaev and Frede (2015, in this volume, pp. 129-148), while the socio-economic settings are analysed in Hansjürgens (2015, in this volume, pp. 169-186).

The water users associations are a central player in the valley's water management sector; therefore, their role and the reasons for their successes and failures are addressed in Moss and Hamidov (2015, in this volume, pp. 149-167).

\subsection{The Lower Jordan River Basin and the Red Sea-Dead Sea Conveyance Project}

The Lower Jordan River Basin stretches from Lake Tiberias (also known as Sea of Galilee, Kinneret or Lake of Gennesaret) to the Dead Sea, the final recipient of the Jordan River (Fig. 7.3). The Jordan River Basin is shared between Lebanon, Syria, Jordan, the Palestine Territories and Israel.

Water management is one of the major issues in the relationship between the people of this region. In the past, water has been both a source of conflict but also the opportunity for cooperation in one of the world's major political hot spots. All riparian states are confronted with an excessive use of the existing water resources, population increase and the impacts of climate change. The over-extraction of water - mainly for agricultural purposes - has led to a constant decline in the Dead Sea level of about $1 \mathrm{~m} /$ year. The consequences are the erosion of the coastal sea line, the formation of sinkholes and the salinisation of groundwater sources around the Dead Sea (see Fig. 7.4).

Lake Tiberias, the major water reservoir of the region, groundwater resources, and the River Jordan itself are also severely impacted by unsustainable water uses. And in the future, water stress will most probably increase.

In order to stop the further decline of the Dead Sea water level and to develop new water sources, Jordan and Israel have proposed that the World Bank finances an ambitious plan consisting of the desalination of water from the Red Sea and conveying the brine to the Dead Sea. The whole scheme is therefore referred to as the "Red Sea-Dead Sea (RSDS) Conveyance Project". The World Bank has agreed to carry out a feasibility study of the project - provided that the Palestine Territories become involved in the project. As a result of the political pressure of NGOs from the environmental sector, the "Study of Alternatives" (Allan et al. 2012) was conducted in addition to an environmental impact assessment.

The non-technical possibilities to restore the natural flow of the Jordan River as an alternative to the major technological solution pursued by the RSDS project, as well as the controversial role of the potash companies, which extract around $300 \times 10^{6} \mathrm{~m}^{3} /$ year of water from the Dead Sea, were among the issues of greatest 


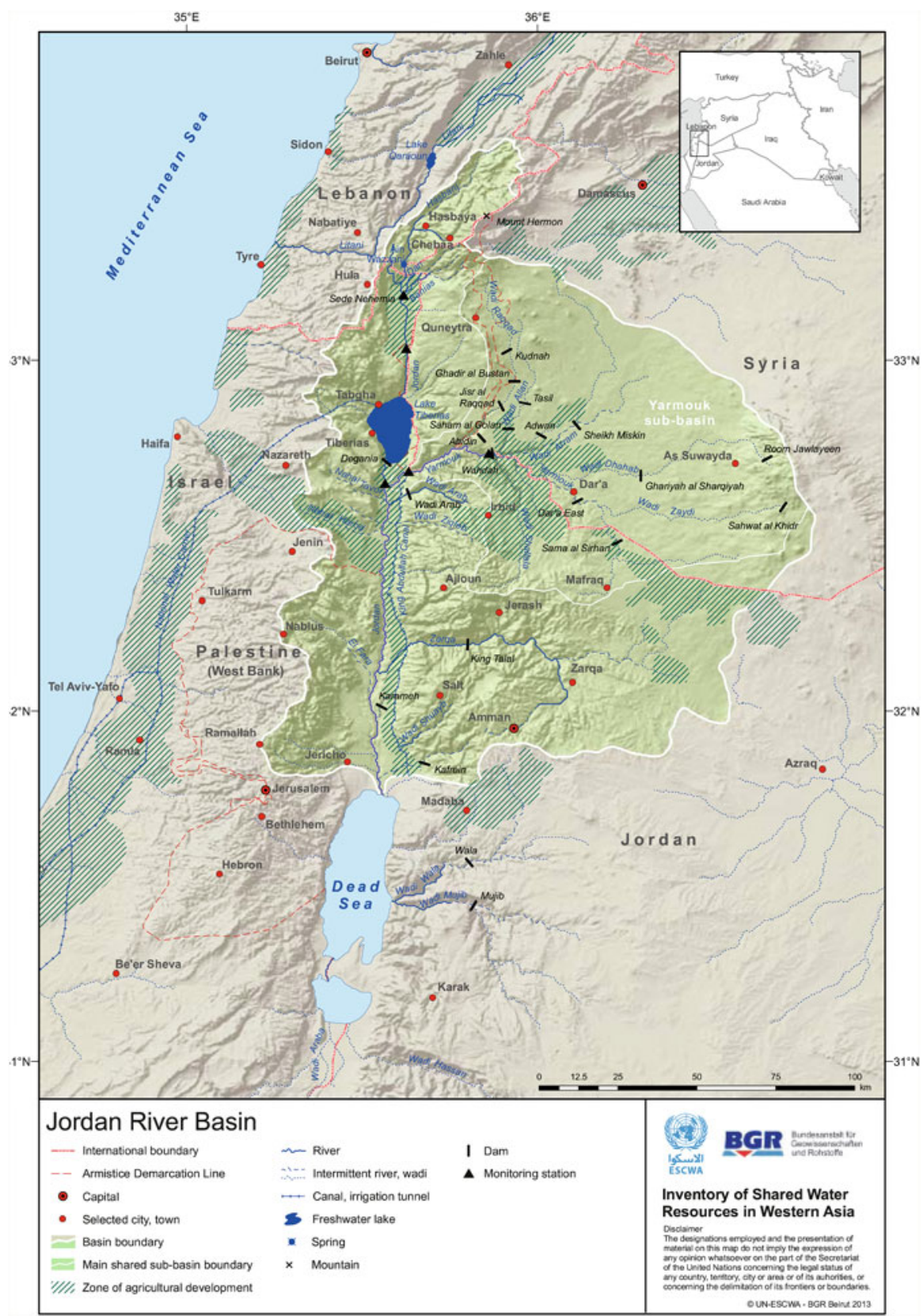

Fig. 7.3 The Jordan River Basin (Source: UN-ESCWA and BGR 2013, p. 173) 


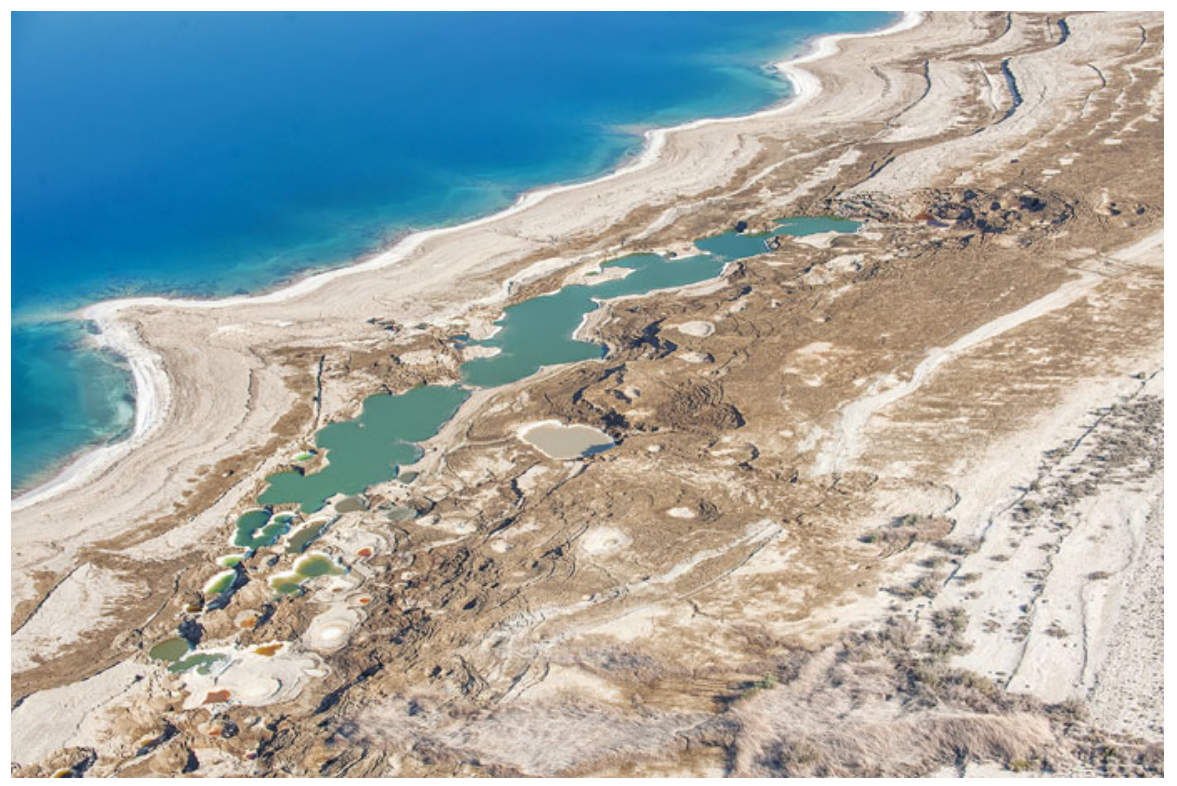

Fig. 7.4 Pronounced erosion sinkholes (Photo: André Künzelmann, UFZ)

public concern and interest. There are environmental concerns regarding the likelihood of breakage or leakage of the conveying pipes, and the probable negative effects this would have on the Arrava groundwater layer. Further ecological threats could arise from the possible formation of gypsum and an algae blossom in the Dead Sea.

Shortly after the finalisation of the study of alternatives, Jordan, Israel and the Palestine Territories signed a memorandum of understanding (MoU) concerning a Red Sea-Dead Sea Conveyance Project as a first stage of a larger project. The MoU foresees a water swap between Israel and Jordan. In a first stage, a desalination plant at Aqaba (Jordan) will be built to produce $80 \times 10^{6} \mathrm{~m}^{3} /$ year of freshwater, of which $30-50 \times 10^{6} \mathrm{~m}^{3} /$ year will be sold to Israel, the remaining being used in Jordan. The brine is supposed to be pumped to the Dead Sea via a pipeline. Jordan will receive water from Beit Zera (Lake Tiberias) via the King Abdallah Canal to secure the water provision of Amman. The Palestine Territories will receive $30 \times 10^{6} \mathrm{~m}^{3} /$ year from the desalination plants on the Israeli Mediterranean coast in return for money (Markel 2014).

Whatever solution will be chosen to overcome the water shortage in the region in the end, cooperation among the riparian states will be essential. With concern to the present political situation, the analysis in this volume will be restricted mainly to Jordan, the Palestine Territories and Israel, even though Syria and Lebanon have a stake in the region's water management as well. Bismuth (2015, in this volume, pp. 189-204) examines the institutional settings, the water management and the specific relationships between the main parties. The Red Sea-Dead Sea Conveyance Project and the planned water swap is studied by Malkawi and Tsur (2015, in this 
volume, pp. 205-225). Jordan's water management will be in the focus of the contribution of Yorke (2015, in this volume, pp. 227-251). Here, the social and institutional obstacles to an improved water management in Jordan are analysed. Bismuth et al. (2015, in this volume, pp. 253-275) focus their analysis on the technical and financial instruments which Israel has introduced to face the water crisis during the last decade.

\subsection{Significance and Exemplary Importance of the Case Studies}

The fates of the Aral Sea and the Dead Sea are both exemplary for the slow decline or even disappearance of many inland lakes under arid climate conditions. Both case studies are relevant exemplary cases of the most common water problems and the role of MWEPs - either as an instrument to solve some of those problems or as a cause of additional problems. The case studies are also examples for the effects of water projects that are mainly based on the advancements of hydrological engineering and on more or less sophisticated technological measures. Furthermore, the river ecosystems affected by these measures are fragile, complex and valuable, and are embedded into a many-faceted societal context characterised by opposed interests. We will focus not only on the frequently unpredictable effects of "technologies" on complex natural systems but also on the roles of the different stakeholders in the decision-making process. The case studies illustrate the insufficient dialogue and exchange between the different scientific disciplines involved, namely the social sciences on the one hand and the technical natural-science-based disciplines on the other. Stimulating such a dialogue and presenting new views on solutions and perspectives is one of the major objectives of our research.

This entire discourse is not only of relevance for water management projects but rather, these findings can be transferred to all major engineering projects at the interface between ecosystems and societies. In view of the increasing numbers of planned MWEPs, some at a larger scale and extent than any other project to date, new approaches are needed, especially when it comes to secure future resources of food, water and energy.

Open Access This chapter is distributed under the terms of the Creative Commons Attribution Noncommercial License, which permits any noncommercial use, distribution, and reproduction in any medium, provided the original author(s) and source are credited.

\section{References}

Allan JA, Malkawi AIH, Tsur Y (2012) Red Sea - Dead Sea water conveyance study program. Study of alternatives. Preliminary draft report. World Bank Publications, Washington, DC

Bismuth C (2015) Cooperation and power asymetries in the water management of the Lower Jordan alley - the situation today and the path that has led there. In: Huettl RF, Bens O, Bismuth C, Hoechstetter S (eds) Society - water - technology: a critical appraisal of major water engineering projects. Springer, Dordrecht, pp 189-204 
Bismuth C, Hansjürgens B, Yaari I (2015) Technologies, incentives and cost recovery: is there an Israeli role model? In: Huettl RF, Bens O, Bismuth C, Hoechstetter S (eds) Society - water technology: a critical appraisal of major water engineering projects. Springer, Dordrecht, pp 253-275

Cariou A (2004) Le jardin saccagé. Anciennes oasis et nouvelles campagnes d'Ouzbékistan. Ann Geogr 113:51-73

Eschment B (2011) Wasserverteilung in Zentralasien. Ein unlösbares Problem? Friedrich Ebert Stiftung, Berlin

Francfort H-P, Lecomte O (2002) Irrigation et société en Asie centrale des origines à l'époque achéménide. Ann Hist Sci Soc 57:626-663. doi:10.3406/ahess.2002.280068

Hansjürgens B (2015) Theory, market and the state: agricultural reforms in post socialist Uzbekistan between economic incentives and institutional obstacles. In: Huettl RF, Bens O, Bismuth C, Hoechstetter S (eds) Society - water - technology: a critical appraisal of major water engineering projects. Springer, Berlin/Dordrecht, pp 169-186

ICWC (2002) II. Diagnostic report on water resources in Central Asia. http://tajikwater.net/docs/ diagnostic_reportwater_080719.pdf. Accessed 17 Feb 2015

Jozan R (2008) "État délinquant" ou modèle déviant? Retour sur le non-respect du traité international de partage de la ressource en eau du Syr Darya. Flux 1:46-60

Jozan R (2012) Les débordements de la Mer d'Aral. Presses Universitaires de France, Paris

Kenjabaev SM, Frede H-G (2015) Irrigation infrastructure in Fergana today: ecological implications - economic necessities. In: Huettl RF, Bens O, Bismuth C, Hoechstetter S (eds) Society water - technology: a critical appraisal of major water engineering projects. Springer, Dordrecht, pp 129-148

Kreutzmann H (2015) From upscaling to rescaling - the Fergana Basin's tranformation from Tsarist irrigation to water management for an independent Uzbekistan. In: Huettl RF, Bens O, Bismuth C, Hoechstetter S (eds) Society - water - technology: a critical appraisal of major water engineering projects. Springer, Dordrecht, pp 113-127

Malkawi A, Tsur Y (2015) Reclaiming the Dead Sea: alternatives for action. In: Huettl RF, Bens O, Bismuth C, Hoechstetter S (eds) Society - water - technology: a critical appraisal of major water engineering projects. Springer, Dordrecht, pp 205-225

Markel D (2014) Viewpoint: the best alternative. In: The Jerusalem Post. 13. Januar. http://www. jpost.com/Jerusalem-Report/The-Region/Viewpoint-The-best-alternative-337129. Accessed 9 Apr 2015

Moss T, Dobner P (2015) Between multiple transformations and systemic path dependencies. In: Huettl RF, Bens O, Bismuth C, Hoechstetter S (eds) Society - water - technology: a critical appraisal of major water engineering projects. Springer, Dordrecht, pp 101-111

Moss T, Hamidov A (2015) Where water meets agriculture: the ambivalent role of the water users associations (WUAs). In: Huettl RF, Bens O, Bismuth C, Hoechstetter S (eds) Society - water technology: a critical appraisal of major water engineering projects. Springer, Dordrecht, pp 149-167

Rekacewicz P, Novikov V (2006) Water withdrawal and availability in the Aral Sea Basin. In: UNEP/GRID Arendal. http://www.grida.no/graphicslib/detail/water-withdrawal-andavailability-in-aral-sea-basin_85d9. Accessed 3 Mar 2015

UN-ESCWA, BGR (2013) Inventory of shared water resources in Western Asia: Chapter 6 Jordan River Basin. United Nations Economic and Social Commission for Western Asia, Federal Institute for Geosciences and Natural Resources, Beirut

Yorke V (2015) Jordan's shadow state and water management: prospects for water security will depend on politics and regional cooperation. In: Huettl RF, Bens O, Bismuth C, Hoechstetter S (eds) Society - water - technology: a critical appraisal of major water engineering projects. Springer, Dordrecht, pp 227-251 